
\title{
$\begin{array}{ll}\text { Research Square } & \begin{array}{l}\text { Preprints are preliminary reports that have not undergone peer review. } \\ \text { They should not be considered conclusive, used to inform clinical practice, } \\ \text { or referenced by the media as validated information. }\end{array}\end{array}$
}

\section{Isolation and Characterization of Microsatellites Markers in Centaurium Grandiflorum ssp. Boissieri}

Vania Jiménez-Lobato ( $\sim$ vania.lobat@gmail.com )

Universidad Autonoma de Guerrero/university of Seville https://orcid.org/0000-0003-2050-9026

Marcial Escudero

University of Seville: Universidad de Sevilla

Zoila Díaz Lifante

University of Seville: Universidad de Sevilla

Cristina Andrés Camacho

University of Seville: Universidad de Sevilla

Alejandra de Castro

University of Seville: Universidad de Sevilla

Juan Arroyo

University of Seville: Universidad de Sevilla

\section{Short Report}

Keywords: Centaurium, Gentianaceae, Mating systems, SSR markers.

Posted Date: June 11th, 2021

DOI: https://doi.org/10.21203/rs.3.rs-522679/v1

License: (a) This work is licensed under a Creative Commons Attribution 4.0 International License. Read Full License

Version of Record: A version of this preprint was published at Molecular Biology Reports on October 13th, 2021. See the published version at https://doi.org/10.1007/s11033-021-06764-5. 


\section{Abstract}

Estimation of outcrossing/selfing rates and characterization of genetic diversity with microsatellite markers are crucial to understand the evolution of mating system in plant species. We developed, optimized and characterized eight new primers pairs for Centaurium grandiflorum ssp. boissieri and transferred them to three subspecies of Centaurium quadrifolium. Two SSR loci were transferred from Sabatia campestris to the four mentioned taxa of Centaurium. Polymorphisms, $H_{e}, H_{o}$ and $\mathrm{H}-\mathrm{W}$ deviations were estimated in two populations of $C$. grandiflorum ssp. boissieri, and in seven individuals of $C$. quadrifolium ssp. barrelieri, $C$. quadrifolium ssp. parviflorum and $C$. quadrifolium ssp. quadrifolium. A total of 80 individuals were used in these experiments. The number of polymorphic loci varied among species from one to ten. A total number of 127 alleles were scored. The average number of alleles per locus was 12.7. $H_{e}$ was higher than $H_{o}$ in all sampled populations. Hardy-Weinberg equilibrium was found for some loci in different species. This is the first report of microsatellites successfully amplified in the whole Centaurium genus. They will be valuable for estimation of mating system parameters, genetic diversity and explore its relationship with the wide flower morphology, especially anther-stigma separation, found along the genus.

\section{Introduction}

The genus Centaurium Hill (Gentianaceae) comprises ca. 27-30 species [1, 2], and is a sub-endemic genus in the Mediterranean basin where most of the diploid taxa occur [3]. The life form vary from annual, biannual to short-lived perennial herbs. Species inhabit dry, open and, in some cases, disturbed habitats for what are considered pioneer species. The flowering season occurs from April to August, depending on species, but generally during warm and dry periods of the year in a typical Mediterranean climate. Only during the morning or at the dusk, when temperatures are milder, pollinators are active otherwise they are null or scarce, reducing the opportunity for crosspollination. The short and unpredictable daily period of pollinator activity suggest the selection of traits to favors the ability of individuals to self-fertilize, facilitating the establishment of predominant selfing populations (i.e. "reproductive assurance" hypothesis) $[4,5,6,7]$. However, the observed wide range of flower features displayed by this genus associated to geological and climatic history of the Mediterranean basin $[8,9]$ point toward a wide variation in mating system among and within species. To determine the level of selfing in natural populations and its relation to flower traits it is necessary to dispose of appropriate molecular markers unequivocally detecting heterozygosity.

We characterized eight new SSR polymorphic markers for $C$. grandiflorum subsp. boissieri and tested them for cross-amplification in other three subspecies of $C$. quadrifolium which is the sister species of $C$. grandiflorum ssp. boissieri. $C$. quadrifolium ssp. barrelieri, $C$. quadrifolium ssp. parviflorum and $C$. quadrifolium ssp. quadrifolium) [9]. This clade has shown a great phenotypic variation in flower size, flower display and herkogamy $[2,9]$, traits related to pollination biology. Further, we describe genetic diversity of three populations of $C$. $g$. boissieri across its distribution range in Andalousía region. The loci will be mainly used to estimate parameters of mating system and its consequences on genetic diversity within and among species of Centaurium. Further, the data also will be used to analyze the relationship between flower morphology and mating system within species. These are the first microsatellite loci developed for the whole Centaurium genus, which is most characteristic of short-lived flora of the Mediterranean, and thus may serve to disentangle crucial questions on the evolution of reproductive strategies in harsh dry and hot seasons.

\section{Materials And Methods}

Genomic DNA was obtained using Invisorb Spin Plant Mini Kit (STRATEC Molecular GmbH, Berlin, Germany) and was extracted from three individuals of $C$. grandiflorum subsp. boissieri belonging to three different populations of Andalucía Province in Spain ("Universidad Pablo de Olavide", Seville [37²1'18.04"N - 556'16.56"O]; "El Bosque", Cadiz [3645'55.14"N - 5²9'48.05"O]; and "Río Frío", Granada $\left[37^{\circ} 09^{\prime} 36.77^{\prime \prime} \mathrm{N}-41^{\circ} 11^{\prime} 07.93^{\prime \prime} \mathrm{O}\right]$, whose vouchers are located in SEV herbarium). Microsatellite libraries were developed by Ecogenics Company.

The design of potential microsatellites loci was outsourced to the company Ecogenics (Schlieren-Zürich, Switzerland, https://www.ecogenics.ch), which combined enrichment for microsatellite motifs in a C. g. boissieri genomic DNA library with 454sequencing on a Illumina Miseq system (Illumina, San Diego, California, USA) with an average read length of 80-400 bp. Using a pipeline property of Ecogenics, a total of 640 microsatellites loci were found, including 263 di-, 352 tri- and 25 tetranucleotides (Table 1). 
Table 1

Characteristics of 10 microsatellite loci for Centaurium g. boissieri based upon genotyping three populations.

\begin{tabular}{|c|c|c|c|}
\hline Locus & Primer sequences $\left(5^{\prime}-3^{\prime}\right)$ & Repeat motif & Allele size range (bp) \\
\hline \multirow[t]{2}{*}{ Boi8 } & F: GAGATGCAACGAGTCGAACC & $(\mathrm{GAA})$ & $161-167$ \\
\hline & R: TCGTAGCCTGAGCCATCTTC & & \\
\hline \multirow[t]{2}{*}{ Boi9 } & F: GCTACCCGAAGTTTTCCGAC & $(A G G)$ & $238-277$ \\
\hline & R: CGAGTTTGACCGAGCCATTC & & \\
\hline \multirow[t]{2}{*}{ Boi16 } & F: ACATGTACGTGCCTCCTAGC & $(\mathrm{TA})$ & $215-233$ \\
\hline & R: TTGGGAGCCAAAAACGCATC & & \\
\hline \multirow[t]{2}{*}{ Boi19 } & F: AATAATCATGGTGGCGCACG & (GTAT) & $156-252$ \\
\hline & R: TGCATACAAGAATTCGCAAAAGC & & \\
\hline \multirow[t]{2}{*}{ Boi23 } & F: TGTGTTGGAAACCGCTAATATCC & (ATGT) & $230-282$ \\
\hline & R: GTGCAAGGCTCACAATCTCC & & \\
\hline \multirow[t]{2}{*}{ Boi32 } & F: GTTAAGATCACACAGCCCGC & (AAT) & $199-238$ \\
\hline & R: GTATGGCTCGTTTCACCTGC & & \\
\hline \multirow[t]{2}{*}{ Boi38 } & F: TGTTCCTACATATACGAGTAAAAGC & (AT) & $238-272$ \\
\hline & R: AATAGGTTCTCAAGAGCCATAAAC & & \\
\hline \multirow[t]{2}{*}{ Boi39 } & F: AATGCAAGGCAAGTTCTCGG & $(\mathrm{GA})$ & $225-253$ \\
\hline & R: TCACGAGAATGGATTGGGGC & & \\
\hline
\end{tabular}

We selected 40 primer pairs within a size range from 100 to 250 bp to be tested on 59 individuals of $C$. grandiflorum ssp. boissieri collected from three different populations. Also, we tested another eight microsatellites designed for Sabatia campestris from the same Tribe Chironieae (Gentianaceae) [10]. The two loci that amplified for C. g. boissieri were also tested for cross-amplification Centaurium quadrifolium, using 7 individuals per subspecies (Table 1). A total of 80 individuals were used. PCR's were performed in 20 $\mu \mathrm{L}$ of reaction mixture containing $60 \mathrm{ng} / \mu \mathrm{l}$ of template genomic DNA, $0.5 \mathrm{U}$ taq polymerase, 1 x My Taq Red Reaction Buffer (Bioline, London, UK), 0.01\% bovine serum albumin (BSA) (Promega, Madison, WI, USA), $0.04 \mu \mathrm{M}$ M13-tailed forward primer, $0.40 \mu \mathrm{M}$ PIG-tailed reverse primer and 0.40 dye-labelled M13 primer (FAM, VIC, NED or PET dyes; Invitrogen, Madrid, Spain), following the methods of Boutin-Ganache et al.[11]. PCR were undertaken using a touchdown PCR protocol on a Veriti 96-Well Fast Thermal Cycler (Applied Biosystems, Foster city, CA, USA). The thermal profile consisted of initial denaturalization at $94^{\circ} \mathrm{C}$ for $2 \mathrm{~min} ; 17$ cycles with denaturalization at $92^{\circ} \mathrm{C}$ for $30 \mathrm{~s}$, annealing at $60-$ $44^{\circ} \mathrm{C}$ for $30 \mathrm{~s}\left(1^{\circ} \mathrm{C}\right.$ decrease in each cycle), and extension at $72^{\circ} \mathrm{C}$ for $30 \mathrm{~s} ; 25$ cycles at $92^{\circ} \mathrm{C}$ for $30 \mathrm{~s}, 44^{\circ} \mathrm{C}$ for $30 \mathrm{~s}, 72^{\circ} \mathrm{C}$ for $30 \mathrm{~s}$; and a final extension of $5 \mathrm{~min}$. at $72^{\circ} \mathrm{C}$. PCR products were analyzed in ABI prism 3130 and 3730 systems (STAB VIDA, Portugal) and sized using Gene Marker 2.4 (SoftGenetics, State College, PA, USA) and Gene Scan 500 LIZ size standard.

We estimated: 1) number of observed alleles $(A), 2)$ observed $\left(H_{o}\right)$ and expected $\left(H_{e}\right)$ heterozygosity, and 3$)$ deviations from HardyWeinberg equilibrium $\left(P H W_{E q}\right)$ using Marcov chain with 100,000 permutations. All analyses were done using Arlequin software v.3.5.2.2 [12].

\section{Results And Discussion}

A total of eight new polymorphic primers pairs plus two cross-amplification loci (Sc205, Sc249) transferred from S. campestris were amplified in four taxa of Centaurium (Table 1). The rest of loci tested were monomorphic for all 80 samples or did not amplified clearly, producing multiple peaks. We scored 127 alleles among all four taxa. The number of alleles per locus varied from 3 (sc249) to 23 (Boi39) with an average of 12.7. In C. g. boissieri all 10 loci were polymorphic with mean $A=7.2$ (range 2-14), $H_{o}=0.46$ (range $0.133-0.867$ ) and $H_{e}=0.704$ (range 0.140-0.931). In C. q. barrelieri, six loci were polymorphic with mean $A=3.833$ (range 2-6), $H_{o}=0.238$ (range 0.0-0.571) and $H_{e}=0.619$ (range 0.264-0.868). Further, two loci were monomorphic and other two did not amplify. In $C$. q. quadrifolium six loci were polymorphic with mean $\mathrm{A}=4.167$ (range 2-6), $H_{o}=0.495$ (range 0.0-0.857) and $H_{e}=0.691$ (range 0.264-0.890); other two loci were monomorphic and two loci did not amplify. Finally, in C. q. parviflorum, only one locus was polymorphic with $A=2, H_{o}=0.0$ and $H_{e}=0.533$. 
Other six loci amplify but were monomorphic and other three loci did not amplify (Table 2). Significant deviations for Hardy-Weinberg equilibrium were found for some loci in different species (Table 1) which can be the result of small sample sizes used, particularly in $C$. $q$. barrelieri, C. q. quadrifolium and C. q. parviflorum.

Table 2

Number of individuals $(M)$, number of alleles $(A)$, observed $\left(H_{o}\right)$ and expected $\left(H_{e}\right)$ heterozygosity, and $P$ value for deviations from HardyWeinberg equilibrium $\left(P H W_{E q}\right)$ tested for 10 microsatellites in four taxa of Centaurium. C. g. boissieri was tested in three localities.

\begin{tabular}{|c|c|c|c|c|c|c|c|c|c|c|c|c|c|c|c|}
\hline \multirow[b]{3}{*}{ Locus } & \multicolumn{15}{|c|}{ C. g. boissieri } \\
\hline & \multicolumn{5}{|c|}{ El Bosque } & \multicolumn{5}{|c|}{ UPO } & \multicolumn{5}{|c|}{ Río Frío } \\
\hline & $N$ & $A$ & $H_{0}$ & $H_{e}$ & $P H W_{E q}$ & $N$ & $A$ & $H_{O}$ & $H_{e}$ & $P H W_{E q}$ & $N$ & $A$ & $H_{0}$ & $H_{e}$ & $P H W_{E q}$ \\
\hline Boi38 & 36 & 11 & 0.278 & 0.886 & 0 & $\mathbb{Q}$ & $\nabla$ & $\nabla$ & $\mathbb{Q}$ & $\nabla$ & 12 & 5 & 0.167 & 0.803 & $0.002 *$ \\
\hline Boi19 & 52 & 7 & 0.538 & 0.762 & 0.069 & 30 & 9 & 0.667 & 0.869 & $0.029 *$ & 26 & 6 & 0.231 & 0.708 & $<_{0.001 *}$ \\
\hline Boi32 & 52 & 13 & 0.731 & 0.901 & 0.088 & 30 & 7 & 0.467 & 0.832 & $0.027^{*}$ & 30 & 10 & 0.667 & 0.839 & $0.019 *$ \\
\hline sc205 & 48 & 10 & 0.583 & 0.845 & 0.085 & 28 & 6 & 0.571 & 0.757 & 0.269 & 30 & 11 & 0.667 & 0.880 & $0.038 *$ \\
\hline Boi9 & 56 & 12 & 0.286 & 0.773 & 0 & 20 & 5 & 0.200 & 0.716 & $\begin{array}{l}< \\
0.001^{*}\end{array}$ & 30 & 5 & 0.267 & 0.694 & $0.001 *$ \\
\hline Boi16 & 58 & 6 & 0.586 & 0.553 & 1 & 28 & 3 & 0.143 & 0.500 & $0.003^{*}$ & 28 & 4 & 0.214 & 0.267 & 0.219 \\
\hline Boi8 & 54 & 3 & 0.630 & 0.561 & $0.002^{\star}$ & 30 & 3 & 0.667 & 0.559 & $0.029 *$ & 30 & 3 & 0.600 & 0.577 & $0.045^{\star}$ \\
\hline Boi23 & 54 & 14 & 0.704 & 0.895 & $0.020^{\star}$ & 30 & 8 & 0.867 & 0.816 & 0.531 & 30 & 10 & 0.467 & 0.885 & $<.001 *$ \\
\hline sc249 & 54 & 2 & 0.148 & 0.140 & 1 & 30 & 2 & 0.133 & 0.405 & $0.020 *$ & 30 & 2 & 0.133 & 0.405 & $0.021 *$ \\
\hline \multirow[t]{3}{*}{ Boi39 } & 58 & 11 & 0.517 & 0.840 & $\begin{array}{l}< \\
0.001 *\end{array}$ & 30 & 12 & 0.667 & 0.931 & $0.007^{\star}$ & 30 & 9 & 0.533 & 0.825 & 0.092 \\
\hline & \multicolumn{5}{|c|}{ C. q. barrelieri } & \multicolumn{5}{|c|}{ C. q. parviflorum } & \multicolumn{5}{|c|}{ C.q. quadrifolium } \\
\hline & \multicolumn{5}{|c|}{ Jumilla } & \multicolumn{5}{|c|}{ Peralta } & \multicolumn{5}{|c|}{ Lillo } \\
\hline Locus & $N$ & $A$ & $H_{0}$ & $H_{e}$ & $P H W_{E q}$ & $N$ & $A$ & $H_{0}$ & $H_{e}$ & $P H W_{E q}$ & $N$ & $A$ & $H_{0}$ & $H_{e}$ & $P H W_{E Q}$ \\
\hline Boi38 & 14 & 2 & 0.571 & 0.527 & 1 & 14 & 1 & $\nabla$ & $\nabla$ & $\nabla$ & 14 & 2 & 0 & 0.264 & 0.077 \\
\hline Boi19 & $\nabla$ & $\nabla$ & $\nabla$ & $\nabla$ & $\nabla$ & $\nabla$ & $\nabla$ & $\nabla$ & $\nabla$ & $\nabla$ & $\nabla$ & $\otimes$ & $\otimes$ & $\nabla$ & $\nabla$ \\
\hline Boi32 & 14 & 6 & 0.429 & 0.846 & $0.015^{\star}$ & 14 & 1 & $\nabla$ & $\nabla$ & $\nabla$ & 14 & 6 & 0.857 & 0.890 & 0.379 \\
\hline sc205 & 10 & 2 & 0 & 0.356 & 0.112 & $\nabla$ & $\nabla$ & $\nabla$ & $\nabla$ & $\nabla$ & 10 & 4 & 0.2 & 0.778 & $0.010 *$ \\
\hline Boi9 & 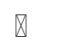 & $\nabla$ & $\nabla$ & $\nabla$ & $\nabla$ & $\nabla$ & $\nabla$ & $\nabla$ & $\nabla$ & $\nabla$ & $\nabla$ & $\nabla$ & $\nabla$ & $\nabla$ & $\nabla$ \\
\hline Boi16 & $\nabla$ & $\nabla$ & $\nabla$ & $\nabla$ & $\nabla$ & 4 & 1 & $\nabla$ & $\nabla$ & $\nabla$ & 10 & 2 & 0.2 & 0.556 & 0.365 \\
\hline Boi8 & 14 & 2 & 0.286 & 0.264 & 1 & 14 & 1 & $\nabla$ & $\nabla$ & $\mathbb{Q}$ & 14 & $\nabla$ & $\nabla$ & $\nabla$ & $\nabla$ \\
\hline Boi23 & 12 & 5 & 0 & 0.848 & $\begin{array}{l}< \\
0.001 *\end{array}$ & 14 & 1 & $\nabla$ & $\nabla$ & $\nabla$ & 14 & 5 & 0.857 & 0.824 & 0.819 \\
\hline sc249 & 14 & $\nabla$ & $\otimes$ & $\nabla$ & $\nabla$ & 14 & 1 & $\nabla$ & $\nabla$ & $\nabla$ & 14 & $\nabla$ & $\nabla$ & $\nabla$ & $\nabla$ \\
\hline Boi39 & 14 & 6 & 0.143 & 0.868 & $\stackrel{<}{0.001 *}$ & 10 & 2 & 0 & 0.533 & $0.048^{\star}$ & 14 & 6 & 0.857 & 0.835 & 0.256 \\
\hline
\end{tabular}

Eight new polymorphic loci characterized in this study and two cross-amplification loci transferred from Sabatia campestris, are the first microsatellites amplified and reported for Centaurium species. These ten loci showed high number of alleles and can be used to characterize mating system in the four species of Centaurium analyzed. However, they also can be tested for other species of the genus. 
The fact that in C. q. parviflorum just one out of seven loci was polymorphic, might indicate a low genetic diversity in this species, which itself could be related to a predominant selfing reproductive strategy that characterizes this species. In this sense, these markers will be crucial to estimate accurately outcrossing/selfing rates in the genus, which in previous studies has been inferred just from flower features and/or the capacity of autonomous selfing of species $[6,7,9]$. Estimation of outcrossing/selfing rates will help to understand the evolution of mating strategies in annual and pioneer species and its implications on the genetic diversity and genetic structure. Particularly in Centaurium, these analyses will enable to explore its relationship with the wide variation of flowers traits found in different species along the phylogeny, and the reproductive mechanisms that allow them to adapt to new disturbed and open habitats.

\section{Declarations}

\section{Consent to participate}

Informed consent was obtained from all individuals participants included in the study.

\section{Consent to publish}

The participants have consented to the submission of the case report to the journal. And declare that the manuscript has not been submitted to more than one journal for simultaneous consideration.

\section{Author contribution}

JA and ME conceived the research topic. VJ-L, ZD-L, CAC and AC performed the field work and gathered the vegetal tissue. VJ-L, ME and AC performed the laboratory work. VJ-L performed the analyses. ME, JA and VJL wrote the manuscript. All authors contributed to the article and approved the submitted version.

\section{Funding}

The research leading to these results received funding from two projects: PGC2018-099608-B-100 and, CGL2013-4503-P, funded by: FEDER / Ministerio de Ciencia e Innovación - Agencia Estatal de Investigación.

\section{Conflicts of interest/Competing interests}

Authors declare no conflict of interest.

\section{Availability of data and material}

Raw Data

\section{Code availability}

Not applicable

\section{Acknowledgements}

We are thankful for facilities provided by the CITIUS-2 centre and especially by the Greenhouse services and Herbarium of the University of Seville (SEV). VJL was supported by a postdoctoral fellowship from CONACYT (\# 252042) and by a contract from the Ministerio de Economía, Industria y Competitividad (CGL2013-45037-P).

\section{References}

1. Mansion G, Zeltner L, Bretagnolle F (2005) Phylogenetic patterns and polyploid evolution within the Mediterranean genus Centaurium (Gentianaceae - Chironieae). Taxon 54: 931-950. DOI: 10.2307/25065479

1. Díaz Lifante Z (2012) Centaurium. In: C. Romero Z, Qintanar A, eds. Flora Iberica. Madrid: Real Jardín Botánico, CSIC, 49-81.

2. Zeltner L (1970) Recherches de biosystématique sur les gen- res Blackstonia Huds. et Centaurium Hill (Gentianaceae). Bull Soc Neuchl Sci Nat 93: 1-164.

3. Schoen DJ, Lloyd DG (1992) Self- and cross-fertilization in plants-III: methods for studyingmodes and functional aspects of selffertilization. Int. J Plant Sci, 153:381-393 DOI 10.1086/297042. 
4. Schoen DJ, Morgan MT, Bataillon T (1996) How does self-pollination evolve? Inferences from floral ecology and molecular genetic variation. Philos. Trans. R. Soc. Lond., B, Biol. Sci. 351(1345):1281-1290 DOI 10.1098/rstb.1996.0111.

5. Brys R, Jacquemyn H (2011) Variation in the functioning of autonomous self-pollination, pollinator services and floral traits in three Centaurium species. Ann Bot-London 107: 917-925. doi: 10.1093/aob/mcr032

6. Brys R, Jacquemyn H (2012) Effects of human-mediated pollinator impoverishment on floral traits and mating patterns in a short-lived herb: An experimental approach. Funct Ecol 26: 189-197. https://doi.org/10.1111/j.1365-2435.2011.01923.x

7. Maguilla E, Escudero M, Jiménez-Lobato V, Díaz-Lifante Z, Andrés-Camacho C and Arroyo J (2021) Polyploidy expands the range of Centaurium (Gentianaceae). Front. Plant Sci. 12:650551. doi: 10.3389/fpls.2021.650551

8. Jiménez-Lobato V, Escudero M, Díaz Lifante Z, Andrés CC, De Castro A, Mansion G, et al. (2019) Evolution of reproductive traits and selfing syndrome in the sub-endemic Mediterranean genus Centaurium Hill (Gentianaceae). Bot. J. Linn. Soc. 191: 216-235. DOI:10.1093/botlinnean/boz036

9. Lyons-Sobaski, Beever JE (2007) Isolation and characterization of microsatellite markers for Sabatia campestris (Gentianaceae), an Illinois state-endangered plant. Mol Ecol Notes 7: 260-262. https://doi.org/10.1111/j.1471-8286.2006.01574.x

10. Boutin-Ganache I, Raposo M, Raymond M, Deschepper CF (2001) M13-tailed primers improve the readability and usability of microsatellite analyses performed with two different allele-sizing methods. BioTechniques 31: 24-26, 28. DOI: 10.2144/01311bm02

11. Excoffier L, Lischer HEL (2010) Arlequin suite ver 3.5: A new series of programs to perform population genetics analyses under Linux and Windows. Mol Ecol Resour 10: 564-567. https://doi.org/10.1111/j.1755-0998.2010.02847.x 